\title{
Promoting non-communicable disease risks in rural area: a Community and Family Health Care - inter professional education (CFHC-IPE) activity
}

\author{
Diannisa Ikarumi Enisar Sangun, ${ }^{1,}{ }^{*}$ Khansa Anindya, ${ }^{1}$ Dea Aryas Nugrahani, ${ }^{1}$ and Niken Kuntolowati ${ }^{2}$ \\ ${ }^{1}$ Department of Obstetrics and Gynecology, Faculty of Medicine, Public Health, and Nursing, \\ Universitas Gadjah Mada, Daerah Istimewa Yogyakarta, Indonesia \\ ${ }^{2}$ Primary Health Care of Ngemplak 2 District, Sleman, Indonesia
}

\author{
Submitted: 16 July 2019 Revised: 9 November 2019 Accepted: 6 December 2019
}

\begin{abstract}
Health is an aspect that could be viewed from various age groups and factors. Risk factors found during Community and Family Health Care-Inter Professional Education visits in Pondok 2, Widodomartani, Ngemplak are the habits of people who still lacking in controlling excessive consumption of sugar, salt, and oily foods. These may lead to many problems such as hypertension, diabetes mellitus and hypercholesterolemia. Based on the problem, our group held the community service activities focusing on health screening, particularly on the measurement of blood pressure, random blood glucose, and total cholesterol level. This activity aims to screen the community health condition and to raise health awareness and understanding. Therefore, people may start to take action improving their lifestyle in order to maintain their long term health status. This research is a retrospective study using secondary data obtained from health examination records at the time of community service. The health check-up was conducted on May 4, 2019. We utilize mannual mercury sphygmomanometer for blood pressure measurement and automatic skin prick test device for random blood glucose and total cholesterol level. During the health examination, we also counsel the subjects about healthy lifestyle. Sixteen people from the targeted community attended the activity. Half of the people had normal blood pressure; 1 person pre-hypertension; 4 persons stage I hypertension, and 3 persons stage II hypertension. For random blood glucose measurement, only 1 resulted in high random blood glucose whilst others were within normal limit. Total cholesterol level was examined to 9 people with history of hypercholesterolemia with the following results; 2 people had high level, 2 people had borderline-high level, and the rest had normal level. Most of the people within the community had good health status. This kind of activity can be routinely conducted not only to screen community health status but also to promote health awareness.
\end{abstract}

KEYWORDS community health, health awareness, health check-up

\section{Introduction}

Health problems in Indonesia are quite high $37 \%$ in 1990 to $57 \%$ in $2015 .{ }^{2}$ In low and middleuntill now. Non-communicable diseases (NCDs) are one of the most common causes of death in Indonesia. ${ }^{1}$ The death trend in Indonesia due to non-communicable diseases has increased from income countries, there are 15 million people who died from non-communicable diseases annually. ${ }^{3}$ Based on Basic Health Survey (Riskesdas) 2018, the prevalence of non-communicable diseases

\footnotetext{
*Corresponding author: Dianisa Ikarumi Enisar Sangun

Department of Obstetrics and Gynecology, Faculty of Medicine, Public Health, and Nursing, Universitas Gadjah Mada, Jl. Farmako, Sekip Utara, Yogyakarta 55281, Indonesia

E-mail: diannisa.ikarumi@gmail.com
} 
has increased compared to the 2013 Riskesdas, including cancer, stroke, chronic kidney disease, diabetes mellitus, and hypertension. ${ }^{4}$ Noncommunicable diseases management consist of detection, screening, and treating disease. It can be used to reduce medical treatment costs and subsequent treatment. ${ }^{5}$

In this case, the area that became the object of our destination was Pondok 2 village, Widodomartani, Ngemplak. We held several events, namely free health checks, which consist of checking blood sugar, cholesterol, and blood pressure. Based on the previous assessment, we found that most of the residents rarely check their health status, especially blood sugar, cholesterol, and blood pressure.

We aimed that by conducting this activity can be a forum to facilitate the community in the health sector. Free health examination for adults and elderly will increase their awareness of their health and the risks of non-communicable diseases in Pondok 2 village such as high blood pressure, hypercholesterolemia and gout. Then, people will become aware to control routinely based on the results of the examination that carried out at the event. Overall, this activity aims to improve the welfare of the people in Pondok 2 village from the health sector by increasing awareness and knowledge to prevent non-communicable diseases.

\section{Methods}

The method used in our program was to conduct a health check which consist of blood pressure, blood sugar, and direct cholesterol and also conduct discussions when there are questions from the residents. This manuscript is written based on secondary data from community health program.

\subsection{Sample selection}

The study used purposive sampling and recruited 16 participants from 10 (ten) householders who have been determined by the Community and Family Health Care-Inter Professional Education (CFHC-IPE) Faculty of Medicine, Public Health, and
Nursing, Universitas Gadjah Mada. The participants were invited to attend the community service event. A purposive sample is where a researcher selects the sample based on the purpose of the sample. ${ }^{6}$ Inclusion criteria included: the resident of Pondok 2, Widodomartani, Ngemplak, Sleman; adult or elderly; able to communicate, and have the willingness to participate in health examinations. Meanwhile, the residents who were not in the place when the health examination was held were excluded.

\subsection{Location, time and duration of activities}

The activity was held on Saturday, May 4th 2019 at the pavilion of one of the residents of RT 06 Pondok 2, Widodomartani, Ngemplak, Sleman. The duration for a health examination is for 60 minutes that was at $11.00-12.00$ a.m.

\subsection{Data collection techniques and data analysis techniques}

The data were obtained from the result of CFHC-IPE health examination then we did the categorized. Blood pressure is classified into 5 categories: normal less than $120 / 80 \mathrm{mmHg}$, prehypertension with systole $120-129 \mathrm{mmHg}$ and diastole less than $80 \mathrm{mmHg}$, stage I hypertension with systole 130$139 \mathrm{mmHg}$ and diastole $80-89 \mathrm{mmHg}$, stage II hypertension with systole more than $140 \mathrm{mmHg}$ and diastole more than $90 \mathrm{mmHg} .5$ Blood sugar levels are classified as normal, prediabetes, and diabetes. 6 Cholesterol levels are divided into 5 categories, which are normal if less than $100 \mathrm{mg} /$ $\mathrm{dL}$, are at risk of having heart disease if 100-129 $\mathrm{mg} / \mathrm{dL}$, borderline high if cholesterol levels are 130$159 \mathrm{mg} / \mathrm{dL}$, high 160-189 mg/dL, and very high if more than equal to $190 \mathrm{mg} / \mathrm{Dl} .7$

\section{Results}

The community was very enthusiastic about taking part in this activity (Figure 1). Based on the results of the examination on the Table 1, it can be seen that in terms of blood pressure 16 people were present 
at the health examination held, 8 of 16 people had normal blood pressure $(\leq 120 / 80 \mathrm{mmHg}), 1$ person had slightly elevated blood pressure or called prehypertension (systole $121-129 \mathrm{mmHg}$ ), 4 people had stage I hypertension (systole $130-139 \mathrm{mmHg}$ or diastole $80-89 \mathrm{mmHg}$ ), and 3 people had stage II hypertension (systole $\geq 140 \mathrm{mmHg}$ or diastole $\geq 90$ $\mathrm{mmHg}$ ).

At the health examination, blood sugar levels were checked for everyone and cholesterol level was for control for people who had a history of hypercholesterolemia. On blood sugar examination using a random blood glucose test method so that health examination participants do not need to fast the night before, in the table 1 , it can be seen that 14 out of 16 people have normal blood sugar levels $(<200 \mathrm{mg} / \mathrm{dL})$ and there is 1 participant who has blood sugar of $402 \mathrm{mg} / \mathrm{dL}$ so that it falls into the category of diabetes ( $\geq 200 \mathrm{mg} / \mathrm{dL}$ ) and

Table 1. Result of health examination Rt 06 Pondok 2, Widodomartani, Ngemplak, Sleman

\begin{tabular}{cccc}
\hline No & $\begin{array}{c}\text { Random } \\
\text { blood } \\
\text { Glucose } \\
\text { (mg/dl) }\end{array}$ & $\begin{array}{c}\text { Cholesterol } \\
\text { (mg/dl) }\end{array}$ & $\begin{array}{c}\text { Blood } \\
\text { pressure } \\
\text { (mmHg) }\end{array}$ \\
\hline 1. & 83 & 179 & $110 / 60$ \\
2. & 79 & 257 & $130 / 70$ \\
3. & 88 & 224 & $130 / 80$ \\
4. & 83 & 186 & $90 / 60$ \\
5. & 90 & 234 & $130 / 78$ \\
6. & 96 & - & $118 / 80$ \\
7. & 133 & 185 & $140 / 90$ \\
8. & 125 & - & $120 / 80$ \\
9. & 84 & - & $140 / 90$ \\
10. & 78 & - & $110 / 70$ \\
11. & 402 & 250 & $120 / 90$ \\
12. & 135 & 192 & $140 / 90$ \\
13. & 92 & - & $100 / 70$ \\
14. & 76 & 172 & $110 / 70$ \\
15. & 100 & - & $130 / 70$ \\
16. & - & - & $125 / 80$ \\
\hline & & &
\end{tabular}

there is one person who refuses to examine blood sugar and cholesterol. For cholesterol checks we performed total blood cholesterol levels to 9 people who had a history of hypercholesterolemia and found that 5 out of 9 people who had a history of hypercholesterolemia had good and controlled total blood cholesterol levels ( $<200 \mathrm{mg} / \mathrm{dL}$ ) while 4 out of 9 people still having high cholesterol levels and even 2 of them fall into the category of high total cholesterol levels $(40240 \mathrm{~m} / \mathrm{dL}$ ) and the other 2 fall into borderline high (200-239 mg / dL).

\section{Discussion}

Based on the results, the health screening program that aims to control public health while simultaneously educating the public about the importance of controlling blood sugar, cholesterol, and blood pressure regularly went well. The health examination participants were enthusiast in asking questions and wanting to know more about health. New information such as the case of high blood pressure, high blood sugar levels, and high cholesterol levels from some participants were obtained. Most of the problems happens to the participants who rarely carried out periodic examinations to the Primary Health Center (puskesmas).

Blood sugar, cholesterol, and blood pressure are some indicators of the risk factors that can trigger non-communicable diseases such as stroke or cardiovascular disease (CVD). ${ }^{10,11,12}$ It is essential to conduct periodic checks and reduces for groups that have history of high blood sugar and high cholesterol include high blood pressure both in the past and in the family to prevent the possibility of non-communicable disease as mentioned above. ${ }^{13}$ The impact of the health examinations is increasing awareness regarding the importance of maintaining personal health through a lifestyle and the importance of doing regular health at the primary health center. ${ }^{14,15}$ Some participants who got higher than normal results were suggested to visit the nearby primary health center. 


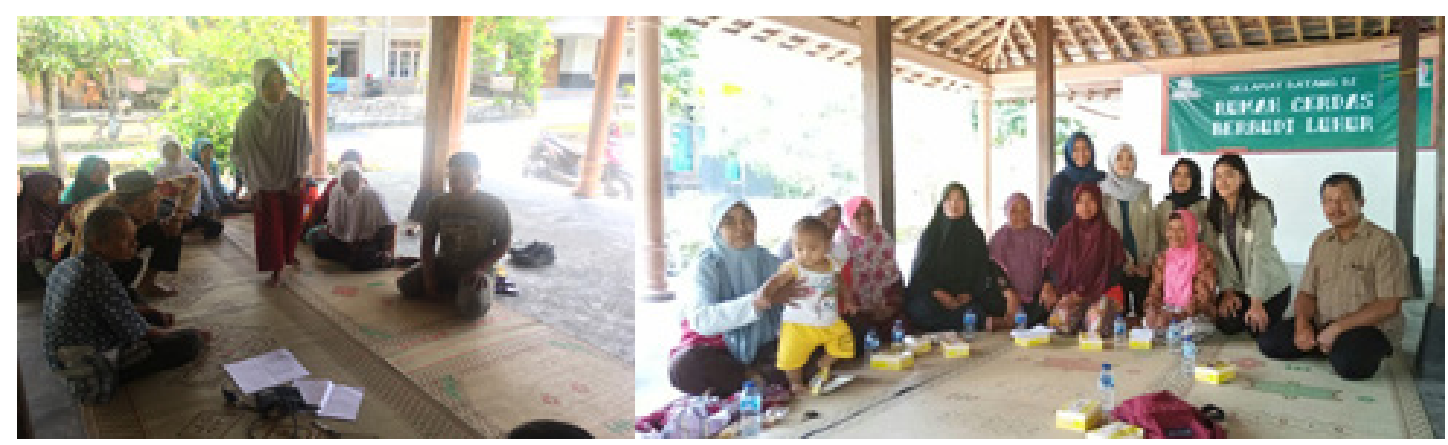

Figure 1. The atmosphere when community service activities are carried out

\section{Conclusion}

Based on the data listed above, we conclude that the level of achievement of our service activities has not been fully fulfilled considering there are still some people who cannot attend health checks for certain reasons. The method used is quite simple and good in accordance with the needs of the community in the area as their daily activities so that a practical matter will greatly help attract their interest in taking a health check.

Our suggestions for further community service activities may be able to further broaden the focus of the target community such as adolescents and children. It should also be considered so that it does not only conduct community service targeting parents and the elderly but also targets the health of young adolescents and children.

\section{Acknowledgement}

The participation and assistance from those villagers Pondok 2, Widodomartani, Ngemplak Sleman, DIY are acknowledged by gratitude. This study was funded by Community and Family Health Care-Inter Professional Education Faculty of Medicine, Public Health, and Nursing, Universitas Gadjah Mada, Yogyakarta.

\section{Conflict of Interests}

The author(s) declared no potential conflict of interest with respect to the research, authorship, and/or publication of this article.

\section{References}

1. Kementerian Kesehatan Republik Indonesia. Penyakit Tidak Menular(PTM) Penyebab Kematian Terbanyak di Indonesia [Internet]. Jakarta: Kementerian Kesehatan Republik Indonesia; 2011 [updated 2011 Agustus 18; cited 2019 July 5]. Available from: http://www. depkes.go.id/article/print/1637/penyakittidak-menular-ptm-penyebab-kematianterbanyak-di-indonesia.html

2. Kementerian Kesehatan Republik Indonesia. Asosiasi Pemerintah Kabupaten Seluruh Indonesia Bersepakat untuk Cegah dan Kendalikan Penyakit Tidak Menular [Internet]. Jakarta: Kementerian Kesehatan Republik Indonesia; 2016 [updated 2016 August 8; cited 2019 July 5]. Available from: http://www. depkes.go.id/article/print/16080900002/ asosiasi-pemerintah-kabupaten-seluruhindonesia-bersepakat-untuk-cegah-dankendalikan-penyakit-tidak.html

3. Garwood, P and Jasarevi, T. 2018. Worls leaders join new drive to beat noncommunicable diseases. Pan American Health Organization.

4. World Health Organization. Noncommunicable Diseases [Internet]. 2018 [updated 2018 June 1; cited 2019 July 5] Available from : https:// www.who.int/news-room/fact-sheets/detail/ noncommunicable-diseases

5. Lembaga Penelitian dan Pengembangan Kesehatan (Litbangkes). 2018. Laporan Hasil Riset Kesehatan Dasar (Riskesdas) Tahun 2018. Kementerian Kesehatan Republik Indonesia.

6. Stephanie. Purposive sampling (Deliberate 
Sampling). Statistic how to [Internet]. 2015 [updated 2015 May; cited 2019 July 5]. Available in https://www.statisticshowto. datasciencecentral.com/purposive-sampling/

7. American College of Cardiology. New ACC/ AHA High Blood Pressure Guidelines Lower Definition of Hypertension [Internet]. ACC Foundation[US] News Story; 2017 [ Updated 2017 November 13; cited 2019 July 5] Available from: https://www.acc.org/latest-incardiology/articles/2017/11/08/11/47/mon5pm-bp-guideline-aha-2017

8. The Global Diabetes Community. Blood Sugar Level Ranges [Internet]. Diabetes.co.uk; 2019 [cited 2019 July 5] Available from: https:// www.diabetes.co.uk/diabetes_care/bloodsugar-level-ranges.html

9. Fletcher, Jenna. What Should My Cholesterol Level be at My Age. [Internet]. Medical News Today. [Updated 2017 February 20; cited 2019 July 5] Available from: https://www. medicalnewstoday.com/articles/315900.php

10. NIDDK. 2017. Diabetes, Heart Disease, and Stroke. National Institute of Diabetes and Digestive, and Kidney Disease.Availabe in https://www.niddk.nih.gov/healthinformation/diabetes/overview/preventingproblems/heart-disease-stroke
11. Sacks FM, et al. Dietary Fats and Cardiovaskular Disease : A Presidential Advisory From the American Heart Association. AHA Journal. 2017; 136(3):e1-e23.

12. Banach M, et al. Association of systolic blood pressure levels with cardiovascular events and all-cause mortality among older adults taking antihypertensive medication. Int J Cardiol. 2014; 176(1): 219-26.

13. Ettehad D, Emdin CA, Kiran A., Anderson SG, et al. Blood pressure lowering for prevention of cardiovascular disease and death: a systematic review and meta-analysis. Lancet. 2016 Mar 5; 387(10022):957-967.

14. Murad MA, et al. Assessment of the Common Risk Factors Associated with Type 2 Diabetes Mellitus in Jeddah. Int J Endocrinol. 2014;2014:616145.

15. Kementrian Kesehatan Republik Indonesia. 2018. Ketahui Tekanan Darahmu Cegah Hipertensi (The Silent Killer). Available in http:// p2ptm.kemkes.go.id/kegiatan-p2ptm/pusat-/ ketahui-tekanan-darahmu-cegah-hipertensithe-silent-killer 